\title{
Concept of the integrative aspects of the forest ecosystem services with case study on recreation services assessment in Slovakia
}

\author{
Vladimir Caboun ${ }^{1}$, Miroslav Kovalcik ${ }^{2^{*}}$ and Zuzana Sarvasova ${ }^{2}$
}

\begin{abstract}
Introduction: This paper presents basic information on the research, classification, and application of the functions of tree species and their communities (mainly forest) in Slovakia. The main aim is a scientific assessment of acquired knowledge regarding the functional effects of forests under real ecological, forest management and socio-economic conditions from various regions in Slovakia; the most up-to-date findings concerning the ecology and economics of natural resources will be applied here. The second part of the paper presents methodological possibilities for valuation of outdoor recreation in forests. Different methods and methodological approaches suitable to a valuation of recreation based on various principles and criteria (preference and non-preference methods, cost-based methods, revenue-based methods, and direct and indirect methods) are analyzed. A practical application of one indirect preference method (travel cost method) is made to evaluate outdoor recreation in forests in Slovakia.

Results and conclusions: A new classification system and a methodology of integrative utilization of forest functions for the forest ecosystem services are constructed. Outdoor recreation in forests, besides recreational forests and areas, assumes the character of a public good: its use by individuals has some influence on utilization by other individuals, and single users cannot be excluded from its utilization. Therefore, some stimulation for its production is missing. In principle, there are no markets for these kinds of public goods and services. The total value of outdoor recreation in forests in Slovakia amounted to €163.4 million; if opportunity time costs were included, this amounted to as much as $€ 825.7$ million.
\end{abstract}

Keywords: Classification of forest functions; Forest functions; Outdoor recreation in forests; Utilization of the functions of forest tree species

\section{Introduction}

Forests and other communities of tree species represent an irreplaceable function in the landscape from the viewpoint of the ecological stability of the landscape, its rational utilization, and sustainable development. Forests represent a basic landscape, forming an ecological and stabilizing element within the landscape. They are the most important source of renewable resources and, thanks to their functions, they also play an important role in the formation and protection of individual components of the natural environment, as well as changes

\footnotetext{
*Correspondence: kovalcik@nlcsk.org

${ }^{2}$ Department of Forest Policy, Economics and Forest Management, National Forest Centre - Forest Research Institute Zvolen, T.G. Masaryka 22, SK-960 92 Zvolen, Slovakia

Full list of author information is available at the end of the article
}

to the environment caused by anthropogenic activities and anthropic activities (artificial environment created by people).

Interrelations of human society and tree species and utilization of their functions have changed in time and space. People's use of the functions of tree species and respective communities in the landscape is subject to the size of the specific human population, the natural conditions, the style of living, and, finally, the social, economic, and cultural development of a society.

In accordance with EU forestry strategy (DirectorateGeneral for Agriculture and Rural Development 1998), one of the basic goals of forest policy in Slovakia (Moravčík et al. 2007) is enhancement of multifunctional (functionally integrated) management of forests and protection of their 
potential functions. We must handle functional potentiality of forests as natural wealth, and preserve and improve it through proper management. Among the most serious problems limiting effective application of the system of multifunctional forest management is a discordance between the social order of forest functions and their economic funding.

Forest management as a production sector survives through the sale of its own products. From this viewpoint, production of the forest functions brings profit, and all other forest functions are merely an encumbrance for forest managers; this means they are not equal to production function. The core of the integration of forest functions is namely mutual comparison and evaluation of various forest functions, their position within the system of forest management, assessment of benefits resulting from various methods, and the interlinking of forest function use into optimal proportions. Forest managers must know which forest benefits society requires, to be able to set the goals of management.

Outdoor recreation in forests, in addition to recreational forests and areas, assumes the character of a public good; its use by individuals has some influence on the utilization of other individuals, and single users cannot be excluded from its utilization (Mavsar 2008). Therefore, some stimulation for its production is missing. In particular, there are no markets for these kinds of public goods and services. To achieve valuation of these forest functions, one must search for appropriate methods and methodical approaches, for example, indirect methods; that is, preference methods.

Evaluation of outdoor recreation in Slovakia as environmental services by using the 'travel cost' preference method is the main aim of this paper.

\section{Methods}

The starting point in Slovakia for a definition and classification of forest function was the ecosystem viewpoint, based on which functions follow from relationships between elements of an ecosystem, surrounding systems and their erroneous feedback (Zachar 1989; Vyskot 1999). Drawing on many ecosystem definitions of forest functions, the following definition was determined: the functions of forests and forest ecosystems are capabilities, effects, and influences appearing in basic components of ecosystems and interaction systems, including human ones. From a socio-economic viewpoint, there is a very large number of definitions of forest functions. We will follow these proposed by Czech colleagues Matejiček (2003) 'Forest functions express the natural and biological characteristics of a forest that form the background and means of satisfying human needs', and Šišák et al. (2006) 'Forest functions express social order, which forestry fulfils in given places, at various times, and under various social conditions'.
In this proposed classification system of forest functions, there are clearly distinct forest functions, which are perceived as the effect of forest on individual components of the environment from the utilization of these functions by a population. A systematic solution of the methodological approach to forest functions and their classification is presented in Figure 1. We distinguish basic forest functions affecting abiotic components of the environment (air, water, soil) and biotic components (plants, animals, microorganisms, human beings). In this way, tree species and their communities fulfil, concerning abiotic components of the ecosystem, edaphic, atmospheric, hydric, and lithic functions, and, concerning biotic components of the ecosystem, phytobiotic, zoobiotic, microbiotic, and anthropic functions in the landscape. In other words, these functions are those which affect the quality and quantity of the effect of tree species and their communities on the soil, climate, water, rocks, plants, animals, microorganisms, and human beings. These functions are divided into partial functions. For example the edaphic function comprises soil forming, soil reclamation and soil protection functions, which consist of erosion control, antideflation, antislide functions, avalanche control, and bank protection function.

A human society may use a complex combination of these functions for economic or social purposes. Then forestry, water management, game management, agriculture, the energy industry, the food industry, the building industry, the chemical industry, the cosmetics industries, the pharmaceutical industry, and so on, belong to anthropic fields, using forest functions in an economic area. Similarly, forest functions may also be used in social areas, that is, for recreation, therapy, hygiene, nature protection, formation and protection of the environment, science and research, education and training, aesthetics and arts, culture and history, and others. In this sense also, the Millennium Ecosystem Assessment (2005) has defined ecosystem service as benefits to humanity from ecosystems. One of the most visible forest functions broadly used by the public is recreation services.

To evaluate outdoor recreation, an indirect preference method was used; the travel cost method. A questionnaire survey was used as the data source for the travel cost method. The target group was a sample of inhabitants above age 14 from the Slovak republic. In the survey, 2,515 respondents were interviewed, out of which 1,732 answered and 783 (31.13) gave no answer. The object of the survey was to ascertain data on the number of forest visits for the previous 12 months for the purpose of outdoor recreation, the length of each forest visit, the distance traveled to a recreational site, and socio-economic data, such as age, income of respondents, and village size, if possible. Other data were to be ascertained as well, such as number of inhabitants in the region to be evaluated, 


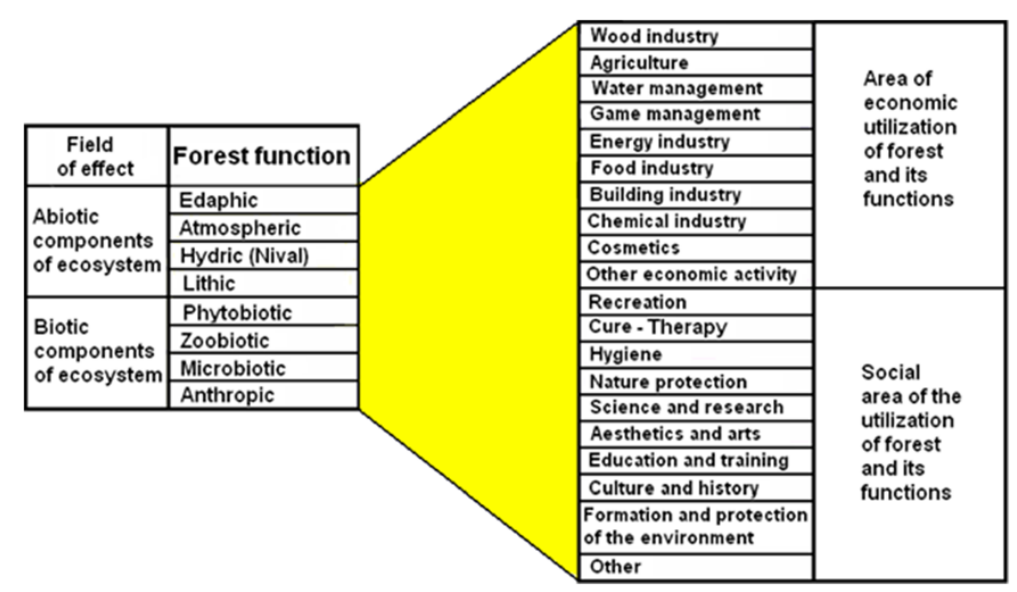

Figure 1 Ecosystem approach to forest and other communities of tree species in the landscape, their functions, and possibilities of function utilization in economic and social fields. (Caboun 2005; Caboun et al. 2010).

travel costs and the opportunity costs of time spent by visiting a forest and traveling.

Three main criteria were set for the achievement of survey representativeness: age of respondents, sex, and region. According to age (Table 1), respondents were divided into three categories: 14 to 30 years old, 31 to 50 and above 51 . The average age of the respondents was 39.7, which in comparison with the average age of the Slovak population, of 38 in 2007, was nearly identical. Concerning sex (Table 2), in the sample there were $53.8 \%$ women and $46.2 \%$ men, which also corresponds with the average for the whole of Slovakia. In the structure of respondents by single regions of Slovakia, respondents from mid- and north Slovakia dominated, but respondents came from 72 districts of Slovakia.

The travel cost method is based on the assumption that the recreational benefits in a specific site can be derived from the demand function, or the estimated observed users' behavior, in relation to the costs sustained by them per number of visits. In other words, the classical model derived from economic theory of consumer behavior postulates that a consumer's choice is based not only on price but on all sacrifices made to obtain the stream of benefits generated by a good or service. Obviously, if the paid price $(p)$ is the only sacrifice made

Table 1 Age distribution of respondents

\begin{tabular}{llllll}
\hline Age & Survey & & & \multicolumn{2}{c}{ Slovakian population } \\
\cline { 2 - 3 } & Number & Percentage & & Number & Percentage \\
\hline 14 to 30 & 622 & 36.27 & & $1,458,324$ & 31.55 \\
31 to 50 & 589 & 34.34 & & $1,581,311$ & 34.21 \\
above 51 & 504 & 29.39 & & $1,582,565$ & 34.24 \\
Total & 1,715 & 100 & & $4,622,200$ & 100 \\
\hline
\end{tabular}

by a consumer, the demand function for a good, with no substitutes, is

$$
x=f(p),
$$

given his or her income and preferences (Rosato and Defrancesco 2002). However, the consumer often incurs other costs $(c)$, in addition to the paid price, that is, disbursements, travel expenses, time loss, and stress from congestion or competition, for example, crowded local markets. In this case, the demand function is:

$$
x=f(p, c) .
$$

In other words, the price is an imperfect measure of the good's cost incurred by the purchaser. Under these conditions, the utility maximizing consumer's behavior should be reformulated, to take into account such costs: given two goods or services $\left(x_{1}, x_{2}\right)$, their prices $\left(p_{1}, p_{2}\right)$, their access costs $\left(c_{1}, c_{2}\right)$ and the consumer's income $(R)$. The utility function can be divided into two parts: one part expresses market goods and services $\left(x_{1}\right)$ and the other part shows public goods $\left(x_{2}\right)$. Now, assume that negligible access costs to the market goods are zero, $\left(c_{1}=0\right)$, but the consumer pays market price $\left(p_{1}\right)$. The access costs are higher for public goods, $\left(c_{2}>0\right)$, but the market price equals zero, $\left(p_{2}=0\right)$, whereby the consumer does not pay for these goods and services. A typical example for this kind of public goods is outdoor

Table 2 Distribution of respondents by sex

\begin{tabular}{llllll}
\hline Sex & Survey & & & \multicolumn{2}{c}{ Slovakian population $(\geq \mathbf{1 4}$ years $)$} \\
\cline { 2 - 3 } \cline { 5 - 6 } & Number & $\%$ & & Number & $\%$ \\
\hline Women & 931 & 53.78 & & $2,398,201$ & 51.88 \\
Men & 800 & 46.22 & & $2,223,999$ & 48.12 \\
Total & 1,731 & 100 & & $4,622,200$ & 100 \\
\hline
\end{tabular}




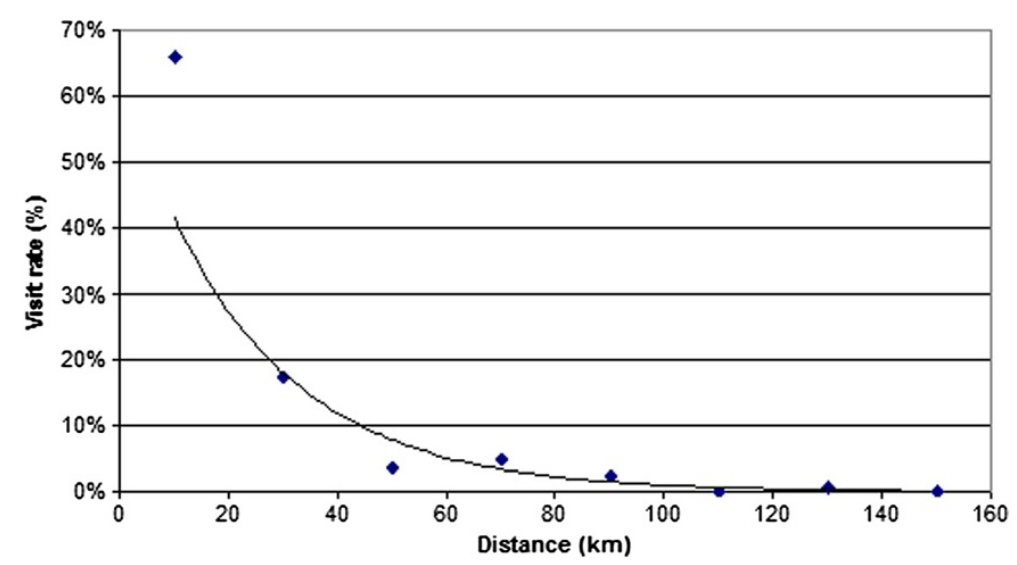

Figure 2 Dependence between visit rate and distance.

recreation in forests; this is free, but its access costs are expressed by travel costs. Under these conditions, the utility maximizing behavior of the consumer depends on:

- The consumer's preferences $\left(u\left(x_{1}, x_{2}\right)\right)$,

- The consumer's budget $(R)$,

- The prices of the private goods and services $\left(p_{1}\right)$,

- The access cost to the recreational site $\left(c_{2}\right)$.

The travel cost method is based on the hypotheses that changes in access costs to the recreational site $\left(c_{2}\right)$ have the same effect as price variations, and that as the number of visits to a site decreases, the cost per visit increases.

\section{Results and discussion}

Results of the travel cost analysis were ascertained by the modified zonal travel cost method on the sample of respondents $(n=1,732)$. An evaluation of results was carried out in two steps: first of all, distances between single recreational sites and the starting point of travel were calculated; the sites were divided into zones, and average visit rates were calculated for these zones. The value of outdoor recreation is calculated in two alternatives: without time costs and with time costs spent on outdoor recreation. Opportunity time costs were calculated on the basis of respondent income and only for employees, entrepreneurs, and part-time employees. Opportunity time costs equaled zero for other groups of respondents, because they had no market income for their work.

To calculate the value of the outdoor recreation by the travel cost method, it was necessary to analyze and statistically describe dependence between the visit rate of the Slovak forests and the average distance of individual places visited. The visit rate was calculated as a quotient of the number of respondents of single zones to all visitors. The exponential form was the best form for describing the data, where the coefficient of determination was the highest (Figure 2).

With the zonal travel cost method, visitors are not separated by transport means, but by transport costs (Löwenstein 1994). Average transport costs were calculated as $€ 0.0175 / \mathrm{km}$ and travel costs (including time costs) as $€ 0.1595 / \mathrm{km}$. Thereafter, the average value of one trip was calculated based on reaction function and average transport and travel costs. The best form of the reaction function was chosen in semi-logarithmic form for both alternatives, using the parameters given in Table 3 .

The reaction function was evaluated using the ordinary least squares method, and the coefficient of determination describes the function's power. As the single parameters were statistically significant in both cases, it is better to use the zone with a width of $40 \mathrm{~km}$. The calculated determination function can be used to calculate the demand function for outdoor recreation as it is dependent on simulated entrance fees. It is assumed that the forest visitors will react in the same way after implementation of simulated entrance fees as to an increase in transport and travel costs.

Figure 3 shows he demand curve for outdoor recreation as a function of transport costs (first alternative: without time costs) and on total travel costs (second alternative: with time costs).

Table 3 Reaction function of zonal travel costs method

\begin{tabular}{lll}
\hline & Zone $\mathbf{2 0} \mathbf{~ k m}$ & Zone $\mathbf{4 0} \mathbf{~ k m}$ \\
\hline $\begin{array}{l}\text { Without time } \\
\text { costs }\end{array}$ & visit rate $=\mathrm{e}^{5.1224-0,0132 \times \operatorname{TrC}}$ & visit rate $=\mathrm{e}^{5.6356-0.0105 \times \operatorname{TrC}}$ \\
$\begin{array}{l}\text { With time } \\
\text { costs }\end{array}$ & visit rate $=\mathrm{e}^{5.1224-0.0029 \times T C}$ & visit rate $=\mathrm{e}^{5.6356-0.0023 \times T C}$ \\
$r^{2}$ & $46.13 \%$ & $81.24 \%$ \\
number of & 21 & 11 \\
zones & &
\end{tabular}

$T C$, travel costs; $\operatorname{Tr}$, transport costs. 


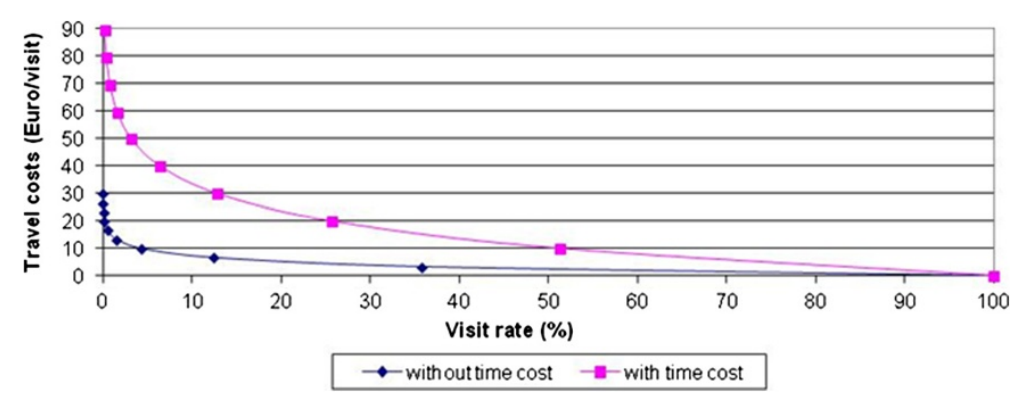

Figure 3 Demand function for outdoor recreation in forests according to travel costs.

The outdoor recreation value was $€ 1.17 /$ visit in the first alternative and $€ 5.89$ /visit in the second alternative (with time costs). The average number of forest visits was about 30.34 (for the case of non-visitors, we calculated using 0). Based on these data, we can determine the average value of outdoor recreation as $€ 35.37 /$ year (without time costs), and as much as €178.63/year (with opportunity costs of time). The number of inhabitants in the Slovak republic above 14 years of age were 4,622,200 individuals in 2007. The total value of outdoor recreation in forests in Slovakia amounted to $€ 163.4$ million, and as much as $€ 825.7$ million, (with opportunity time costs), as shown in Table 4. The final results could be considered overvalued, owing to domination of respondents from the middle and northern parts of Slovakia, which have higher forest coverage and a higher rate of forest visitors for recreational purposes, which can be anticipated in highly forested regions.

\section{Conclusions}

On the basis of current knowledge and the latest approaches to forest functions, and functions of forest tree species and their communities, the method of functional integration seems to be more effective and more pragmatic than the method of purposeful differentiation and

Table 4 Value of outdoor recreation in Slovakia by the travel cost method

\begin{tabular}{|c|c|c|c|}
\hline Indicator & Unit & 1. Variant & 2. Variant \\
\hline \multirow[t]{2}{*}{ Value of one visit } & \multirow[t]{2}{*}{$€ /$ visit } & 1.17 & 5.89 \\
\hline & & 0.95 to 1.38 & 5.30 to 6.47 \\
\hline $\begin{array}{l}\text { Average number } \\
\text { of forest visits }\end{array}$ & Number per year & 30.34 & 30.34 \\
\hline \multirow{2}{*}{$\begin{array}{l}\text { Value of outdoor } \\
\text { recreation per year }\end{array}$} & \multirow[t]{2}{*}{$€ /$ year/person } & 35.37 & 178.63 \\
\hline & & 28.90 to 41.84 & 160.87 to 196.40 \\
\hline $\begin{array}{l}\text { Number of } \\
\text { inhabitants in } \\
\text { the Slovakia } \\
\text { above } 14\end{array}$ & number & $4,622,200$ & $4,622,200$ \\
\hline \multirow{2}{*}{$\begin{array}{l}\text { Total value of } \\
\text { outdoor recreation } \\
\text { in Slovakia }\end{array}$} & \multirow[t]{2}{*}{$€$ million } & 163.47 & 825.69 \\
\hline & & 133.59 to 176.66 & 743.58 to 907.79 \\
\hline
\end{tabular}

prioritization of some of the functions. The application of scientific knowledge to forest functions, forest tree species and their communities and the opportunities for their use in the landscape will enable not only their real use in the environment, but also the construction of a new classification system of the functions of forests, forest tree species and their communities, considering an ecological and, subsequently, economic approach. This approach presupposes the construction of basic typology and a system for the assessment of forest function potential as well as the assessment of real fulfilment of the functions for forest growth in various site conditions, various types of landscape (various use and degree of anthropic changes), with regard to the health condition of real forest, its current tree species composition, age and spatial structure, its ecological stability, taking into consideration expected global and regional (mainly climatic) changes, with regard to social requirements and the interests of the owners of forests.

A real assessment of the benefits of nature and human activities and their influences on human population and nature should be used in socio-economic and ecological methodical procedures in the assessment of ecosystems functions, and from the viewpoint of prospects for survival of nature and human populations. It follows from the analysis and assessment of information and methodical approaches in the evaluation and valuation of the benefits of ecosystems functions and production activities that the most problematic and least exact is evaluation and valuation of benefits, which have not recently been and will not be an object of market realization.

\section{Competing interests}

The authors declare that they have no competing interests.

Authors' contributions

All authors read and approved the final manuscript.

\section{Acknowledgements}

This publication is the result of the project implementation: Extension of the centre of Excellence 'Adaptive Forest Ecosystems', ITMS: 26220120049, supported by the Research \& Development Operational Programme funded by the ERDF. 


\section{Author details}

'Department of Forest Ecology and Landscape, National Forest Centre Forest Research Institute Zvolen, T.G. Masaryka 22, Zvolen, SK-960 92, Slovakia. ${ }^{2}$ Department of Forest Policy, Economics and Forest Management, National Forest Centre - Forest Research Institute Zvolen, T.G. Masaryka 22, SK-960 92 Zvolen, Slovakia.

Received: 4 November 2013 Accepted: 18 May 2014

Published online: 26 July 2014

\section{References}

Caboun V (2005) Spatial arrangement of the territory - determining of ecological functional areas within the project 'Revitalization of forest ecosystems on the territory of the High Tatra Mts. affected by wind calamity on 19.11.2004', Ecological Studies VI. Metamorphoses of the nature protection in the Tatra Mts. Slovak Ecological Society. Slovak Academy of Sciences, Bratislava, pp 126-136

Caboun V, Tutka J, Moravcik M (2010) Excertation of forest functions in landscape. National Forest Centre, Zvolen

Directorate-General for Agriculture and Rural Development (1998) The EU Forestry Strategy., http://ec.europa.eu/agriculture/fore/forestry_strategy_en.htm. Accessed 31 January 2011

Löwenstein W (1994) Reisekostenmethode und bedingte Bewertungsmethode, Ein ökonomischer und ökonometrischer Vergleich, Schriften zur Forstökonomie. Frankfurt am Main, JD Sauerländer

Matejiček J (2003) Determination of basic terms and relationships from out of production forest functions field. VÚLHM, Strnady, Prague

Mavsar R (2008) Valuation studies of non-market forest goods and services in Europe. Plenary lecture I. In: International conference for the integral valorization of the forest, Santiago de Compostela

Millennium Ecosystem Assessment (2005) Ecosystems and human well-being: synthesis. Island Press, Washington DC

Moravčík M, Novotný J, Toma P (eds) (2007) Národný lesnícky program Slovenskej republiky (Slovakian National Forest Programme) MPSR. NLC-LVU Zvolen, Bratislava

Rosato P, Defrancesco E (2002) Individual travel cost method and flow fixed costs. FEEM Working Paper Series. Available at: http://papers.ssrn.com/sol3/ papers.cfm?abstract_id=318684. Accessed 16 June 2014

Šišák L, Šach F, Kupčák V (2006) Expression of social effectiveness of existence and utilization of forest functions in financial form in Czech Republic. Czech University of Life Sciences, Prague (in Czech)

Vyskot I (1999) Potentials of forest functions in Czech Republic by management complexes and stend types. Ministry of the Environment of the Czech. Republic, Prague (in Czech)

Zachar D (1989) The brief characteristics of forest functions. In: Valuation of forest functions and its compounds. VÚLH Zvolen, Bratislava, pp 8-11, in Slovak

doi:10.1186/s13717-014-0015-8

Cite this article as: Caboun et al: Concept of the integrative aspects of the forest ecosystem services with case study on recreation services assessment in Slovakia. Ecological Processes 2014 3:15.

\section{Submit your manuscript to a SpringerOpen ${ }^{\circ}$ journal and benefit from:}

- Convenient online submission

- Rigorous peer review

- Immediate publication on acceptance

- Open access: articles freely available online

- High visibility within the field

- Retaining the copyright to your article

Submit your next manuscript at $\gg$ springeropen.com 